\title{
STRATEGIC AIRLINE ALLIANCES AS A SPECIAL FORM OF COMPANY INTEGRATION
}

\author{
Oksana Kyrylenko ${ }^{1}$, Viktoria Riazanovska $^{2}$, Valentina Novak ${ }^{3}$
}

\begin{abstract}
The purpose of the article is to analyse the world practice of organization and functioning of strategic alliances as one of the forms of integration of companies and consider the peculiarities of their functioning, including in aviation. Initially, their creation was aimed at achieving comparatively simple goals such as regional or global coordination of sales or distribution of innovations and new proprietary technologies in related industries. Economic motivation was to reduce the cost of global marketing or the spread of technology, as well as to increase sales through stable partnerships or cooperative ties. Subsequently, international strategic alliances have continued. The methodology of the research is the position on the theory of enterprise management, as well as the methods of differentiated and component analysis for the scientific definition of the term "strategic analysis." It also describes the differences in strategic alliances from other organizational forms of company integration. The results prove that global competition is not the only reason for the creation of international strategic alliances. The market conditions and technological factors of development, which are derived from the determination and properties of alliances themselves, are determined, but at the same time, they have their own peculiarities, which are dictated by the state of economic life. The emergence of alliances was the result of increased global competition, and especially non-price. However, global competition is not the only reason for the creation of international strategic alliances. In addition, it is also useful to refer to market conditions and technological development factors that derive from the definition and properties of the alliances themselves, but at the same time, they have their own peculiarities that are dictated by the state of the economy. It is practically grounded that one of the motives for the creation and effective development of strategic alliances in the aviation sector is the possibility of improving the level of service. The main problems of creating alliances, regularities of successful functioning, and the main causes of the collapse of alliances are described. Value/originality. Based on the analysis of the problems that arise in the functioning of alliances, the authors proposed some ways to solve these problems and, accordingly, overcome the causes of the collapse of international strategic alliances.
\end{abstract}

Key words: strategic alliance, airline alliance, international strategic alliances, transport, management.

JEL Classification: A19, B41

\section{Introduction}

In world practice, different types of integration of firms have developed, which differ depending on the objectives of cooperation, the nature of economic relations between their participants, the degree of independence of enterprises incorporated in the association. These are strategic alliances, consortia, cartels, syndicates, bullets, associations, conglomerates, trusts, concerns, industrial holdings, financial and industrial groups, etc.

Organizational forms of corporate associations that differ significantly in terms of the degree of integration of their participants are historically developed from

\footnotetext{
Corresponding author:

${ }^{1}$ National Aviation University, Ukraine.

E-mail: ons@ua.fm

${ }^{2}$ National Aviation University, Ukraine.

E-mail: ryazanovskaya@ukr.net

${ }^{3}$ National Aviation University, Ukraine.

E-mail: novakv.nau@gmail.com
}

concerns and family groups to strategic alliances, and so on. At the same time, the organizational forms that arise do not supplant the previous types of integration of companies but complement them. There is an expansion of forms. The nature of the interconnections, especially in aviation branch, between companies becomes more complex and rather subtle, given also the possibility of cooperation of integrated structures.

The purpose of this article is to analyse the world practice of organization including companies in aviation branch and operation of strategic alliances as one of the forms of company integration, analysis of their characteristics, features and differences from other 
forms of integration; the study of problems that arise in the functioning of alliances, the identification and coverage of the main causes of failure and the collapse of strategic airline alliances, as well as consideration of some ways to solve these problems and, accordingly, overcome the causes of the collapse.

\section{Analysis of recent research and publications}

Modern world integration processes, the forms in which they occur, in particular, strategic alliances, are the subject of research by many economists. Among them are such scholars as: (Bobina, Grachev, 2006), (Dagaev, 2001), (Karapukhina, 2004), (Yolles, 2005), and others. The boundaries between the forms of company integration are often blurred. Therefore, different specialists (both theoreticians and practitioners) are sometimes interpreted ambiguously. For example, there are two opinions about the relationship between strategic alliances and consortia (Baum, Rowley, Shipilov, 2004), (Novak, 2012). One of them is that the consortium is not a strategic alliance; however, it is often more of a prevailing point of view that consortia are among the types of strategic alliances.

However, due to the importance of the research, there is a need for further research development of the perspective of the future functioning of international strategic alliances in Ukraine.

The incompleteness of scientific developments in this area and the essential practical significance of this problem for Ukrainian enterprises in the conditions of globalization of the economy emphasize the objective nature of the relevance of the research topic.

\section{Strategic alliance and forms of company integration}

Creation of various international associations of companies at the present stage becomes an objective necessity and a habitual phenomenon. One of the many forms of manifestation of these processes is the creation of international strategic alliances. International strategic alliances are developing in many spheres of the world economy, first of all - in telecommunications, computer science, air transportation, services, etc. (Dagaev, 2001), (Harrigan, 2002), (Novak, 2009).

The Strategic Alliance, according to the authors, is such an organizational form of economic cooperation between two or more independent enterprises for achieving certain commercial goals, obtaining synergy from the combined and complementary strategic resources of companies, in which each of the parties concerned is interested in mutually beneficial cooperation and tries to implement it, moreover, acts as an equal partner and makes a concrete contribution to the achievement of the overall result, while preserving its independence. From the creation of strategic alliances, the company receives significant competitive advantages, so the desire for such integration and its causes are quite understandable. Strategic alliances are the most promising form of company integration and one of the most important means of competition. Their creation is one of the fastest and cheapest ways to implement a global strategy.

Strategic alliances have certain features, namely generalized by (Bobina, 2006), (Dagaev, 2001), (Kyrylenko, 2011), (Yolles, 2005), (Novak, 2009):

- the alliance, as a rule, is not an independent legal entity;

- companies may be members of many strategic alliances;

- this form of economic association is based on the conclusion of medium-term or long-term, bilateral or multilateral agreements;

- strategic alliances are created on the basis of horizontal inter-firm cooperation, as well as between companies engaged in related fields of business and possess complementary technologies and experience;

- strategic alliances are flexible enough, free for partners, more focused on the future, reduce uncertainty in partner relationships, increase stability in resource provision and product and service distribution;

- alliances are created for a certain period of time, they collapse when the need for association disappears;

- in the strategic alliance, not only suppliers and customers can enter, but also competitors;

- alliances have an impact on competition: united companies focus more on joint ventures than one against each other;

- within strategic alliances, the joint coordination of strategic planning and management of participants is carried out, which allows them to coordinate their long-term partnerships with the benefit of each participant;

- this is an agreement on cooperation between firms that goes beyond ordinary commercial transactions but does not bring the case to the merger of companies.

- there are significant differences between strategic alliances based on long-term partner relationships and contract-based partnerships since the latter type of cooperation exists for a limited time and is used for specific projects or purposes. Conventional contractual relations, as a rule, do not foresee the development of relations in the future;

- to date, these are the least restrictive methods of penetration of the market by the legislation.

Strategic alliances are a relatively new formation in the global economy. Initially, their creation was aimed at achieving relatively simple goals such as regional or global sales coordination or the spread of innovations and new patented technologies in related industries. Economic motivation was to reduce the 
cost of global marketing or the spread of technology, as well as increased sales through stable partnerships or cooperative ties. Subsequently, international strategic alliances became long-lasting. They are complex in nature because they are formed for the realization of strategic goals - creation and spread of new technologies and products, the cooperation of production, joint provision of services, etc.

Differences of strategic alliances from other organizational forms of integration of companies are presented in Figure 1, where their comparative characteristics are shown.
The emergence of alliances was the result of increased global competition, and especially non-price. However, global competition is not the only reason for the creation of international strategic alliances. In addition, it is also useful to refer to market conditions and technological and technological factors of development, which follow from the definition and properties of the alliances themselves, but at the same time, have their own characteristics, which are dictated by the state of economic life.

(Completed on the basis of (Litvinenko, 2014), (Bamford, Gomes-Casseres, Robinson, 2002), (Bleeke, Ernst, 2001))
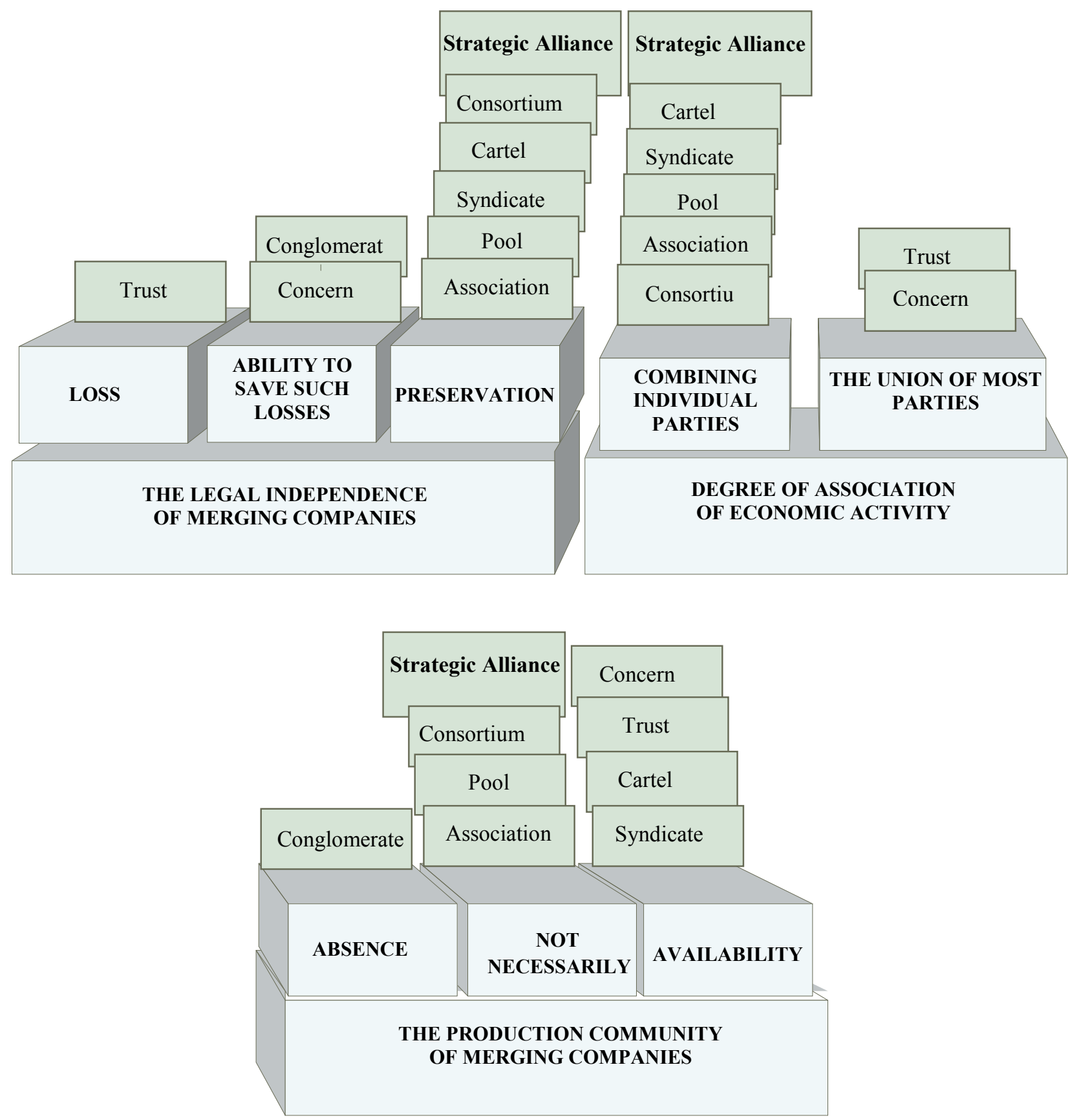

Figure 1. Common features and differences between the main organizational forms of company integration 
These factors include the following:

- further globalization of markets, expansion of the spectrum of geopolitical tasks of development;

- technological universalization of economic activity of entrepreneurial structures;

- fluctuations in the ratio of the exchange rates of individual national currency units;

- objective needs for manoeuvre in investment policy;

- possibility to provide additional transaction savings, to save on expenses;

- an opportunity to increase the profitability of assets, which is provided by deepening of specialization and organizational and managerial optimization;

- further technological progress, which leads to inexpediency, and sometimes entrepreneurial impossibility to follow parallel courses of development of scientific and technological progress.

The goals for which the companies enter strategic alliances are significantly different.

However, the undeniable conditions for the effective functioning of the strategic alliance are long-term planning, policy coordination that strengthens the trust of partners and the desire for cooperation between higher and middle management of allied companies.

There are four types of strategic alliances:

- alliances with joint stock companies in existing enterprises;

- strategic alliances with the creation of new companies (joint ventures);

- consortia for the implementation of investment projects;

- alliances with weak cooperation (Dagaev, 2001).

However, it should be noted that strategic alliances are not devoid of risks, which often lead to failures and collapse of alliances. That is why it becomes necessary to identify not only the basic patterns of successful development but also the reasons for the collapse of international strategic alliances.

Creation and development of international strategic alliances are aimed at the use and creation of certain competitive advantages. Through the use of competitive advantages, the results of alliances are much more significant. As a rule, this is achieved through the possibility of manoeuvring productive resources and individual components of production potential, accelerated implementation of the achievements of NTPs, increasing the efficiency of all marketing activities and economies of scale.

It should be noted that in addition to competitive advantages, alliances are also based on the mutual coherence of the long-term strategic plans of the partners and the main objectives of their activities (for example, increase in the cost of productive efficiency, increase of innovations and knowledge, flexibility and scale of activity, preservation and strengthening of competitive advantages.

\section{A strategic alliance in the aviation sector}

One of the motives for the creation and effective development of strategic alliances in the aviation sector is the possibility of increasing the level of service, which is their significant competitive advantage. Of course, the service is provided by other companies. Therefore, strategic airline alliances make a joint purchase of aircraft, reducing the cost of leasing, since the aircraft are operated more.

Airlines that are a part of strategic airline alliances distribute operating costs, that is, the costs of corporations in terms of the number of places that the company has. Due to such alliances, the company gains new regions or distributes flights that are in less demand.

Airlines take part in regular consumer programs. Permanent consumers are individuals who regularly use the services of companies that are a part of the alliance. Airlines participation in consumer programs provides benefits to consumers as opportunities are available:

- simultaneous purchasing of tickets on a global scale and at low prices;

- the introduction of additional requirements for hotel services, car rentals, communications, etc.;

- replacement of tickets between airlines;

- the implementation of the most convenient flights on a global scale.

Thus, the strategic nature of global alliances is determined by the fact that their members are direct or indirect global competitors or partners in related fields of activity. The development of strategic alliances leads to the distribution of costs and profits, mutual ownership of shares.

An analysis of the global experience of the creation and operation of strategic alliances proves an interesting phenomenon: companies that are not a part of strategic alliances are significantly more likely to fail than the components of the system. Of course, strategic alliances are not completely stable, because firms are changing: some disappear, others appear. However, the position of alliances is much stronger than companies not incorporated into alliances.

Despite the rather high stability of alliances, their creation does not always give the expected effect and brings the desired result. Statistics show that about $60 \%$ of alliances collapse without overcoming the fouryear threshold from the moment of their creation, and ten-year cooperation is rarer (Karapukhina, 2004), (Kyrylenko, 2011). The reasons may be different: insufficiently accurate calculations of the profitability of a joint project, different views on management and marketing, etc.

The study of strategic alliance activities revealed four main problems of creating alliances or four reasons for the collapse of alliances. Namely:

- inconsistency in the size of alliances to the needs and goals; 
- insufficient quality of alliance members;

- internal competition in the alliance;

- problems of managing the alliance system (Novak, 2009).

An analysis of the activities of international alliances shows that for the division of risk or strengthening the position of the market the best possible number of partners.

However, if the main motive for creating a strategic alliance is technological cooperation, the quality factor of the partners becomes the determining factor.

It is also dangerous to take several companies at once to a strategic alliance. As the world practice shows, it is expedient to expand the alliance gradually. This is the best and most consistent mechanism for creating a trusted alliance.

That is why, in order to avoid failure, the creation of a strategic alliance should be aimed not at the size of the alliance as much as possible, but in the compliance of the alliance with the needs and objectives of the participating companies.

The leading factor in the success of alliances is the quality of its participants. The imperfection of this factor can lead to ineffective and inefficient functioning of the strategic alliance, and as a result - to the failure and collapse of the alliance.

Alliance partners should best complement each other's capabilities. For the most accurate identification of potential partners, the company must identify a list of its capabilities, as well as a list of its weaknesses, that is, what it lacks for its successful operation. Then you should follow the partners who will fill these weaknesses.

The result of well-chosen members of the alliance is the unification of several successful developments. One company, for example, offers technology, another resources, the next - a design, one more provides its trading network, customer base, etc.

Internal competition in the alliance is a significant factor that can be broken by any international strategic alliance. But, provided the alliance is properly formed, it should not arise - the participants should complement each other, rather than compete.

For example, if one of the participants shares knowledge and experience with the alliance partners on the production process, market and sales, while others will only try to take this experience and use the knowledge gained for their own purposes, this will inevitably lead to the collapse of such a strategic alliance. Avoid the occurrence of such a problem due to a properly agreed and documented warranty contract.

Another problem may arise on the basis of coincidence of strategic intentions. This usually happens when a strategic alliance includes both small companies and powerful ones. Smaller companies can win significantly more from this alliance. After all, they are involved in the strategic planning, technology, experience, and knowledge of large and smaller turnaround companies. And if they can translate all this much faster than powerful companies, then this will give them the opportunity to first capture new market segments.

Working on the same products, you can avoid such problems by focusing on different levels of product value creation. One firm member of a strategic alliance, for example, can conduct basic research, and the other one can engage in marketing activities and sales. Yes, they cannot exist without one.

The problem of managing the alliance system is quite serious. Management structure dictates the management process.

One of the management systems is used when there are many partners and nobody dominates. Its drawback is the slowness of today's market. If a strategic alliance includes many similar partners with similar interests, then they will be constantly and futilely competing.

The structure of the centre and the periphery, which includes one or more closely interconnected members of the nucleus and smaller partners that rotate around the centre, is more effective. The problem with such a management system can be only a significant increase in the network.

Another, equally effective management system can be based on the leadership of one company. This is the situation of the dominant company. For example, Boeing. Instead of three firms, one Boeing solves all disputes, takes responsibility and disciplines. In this case, the leader must necessarily be a large and authoritative company.

In order for the positive effect of the company's entry into a strategic alliance prevailing over the negative, in our opinion, it is necessary to take into account the following:

- strategic alliance partner must be compatible with this company;

- one should not expect an immediate return on the alliance, largely depending on the trust that exists between companies;

- a strategic alliance should be considered as a temporary agreement between partners, if it becomes disadvantageous, it is expedient to immediately break it. - the most successful alliances are characterized by the fact that products and positions on the partner market complement the products and positions of the company, and do not compete with them;

- as a part of a strategic alliance, it is dangerous to pass on to the partner information that may appear in a competitive situation;

- when creating a strategic alliance, it is recommended that you quickly and comprehensively familiarize yourself with the main ideas and practices of a technology and management partner and introduce the most rational of this in your activity. 


\section{Conclusions}

We consider it expedient to attribute strategic alliances to the so-called soft forms of company integration. These forms of integration are especially popular for international associations, as they allow for joint activities while maintaining the legal and economic independence of the participants. Within the framework of strategic alliances, the opportunity to mobilize the benefits of a strong corporate structure with the preservation of the national secrecy of its members. Indeed, sometimes the state power and public opinion of the countries for certain reasons, and above all, political, are not attentive to such forms of integration of companies, which lead to the loss of independence.

From the creation of international strategic alliances, the company gains significant competitive advantages, so the desire for such integration and its causes are quite understandable. According to the authors, the creation and further development of strategic aviation alliances of the airline are pushed by various factors and motives. The most significant of these is that the company in this case receives a significant gain, which is the following:

- in raising the level of service in the implementation of air transportation;

- in the formation of a customer supply network, which stabilizes the demand for services;

- reduction of fixed and operating expenses;

- in achieving economies of scale - the distribution of fixed costs for another volume of sales;

- in creating new types of income;

- access to foreign markets with minimum costs without additional costs for equipment, purchase of a license for flights;

- in creating competitive advantages over other companies;

- in improving the safety of air transportation.

\section{References:}

Bobina, M. A., Grachev, M. V. (2006). Mezhdunarodniy bisness. Strategiya alyancov [International business. Alliances strategy]. Moscow: Izdatelstvo Dello. (in Russian)

Dagaev, A. A. (2001). Mezhdunarodnyie strategicheskie tehnologicheskie alyansyi rossiyskih predpriyatiy $\mathrm{v}$ oblasti telekommunikatsiy. [International strategic technologic alliances of Russian enterprises in the field of telecommunications]. Moscow: Menedzhment v Rossii i za rubezhom. (in Russian)

Karapukhina, E. A. (2004). Mezhdunarodnyie strategicheskie alyansyi. Opyt issledovania [International strategically alliances. Research experience]. Moscow: Delo i service. (in Russian)

Litvinenko, L. L. (2014). Upravlinnya potencialom integratsiii aviakompanii $\mathrm{v}$ umovah mizhnarodnogo konkurentnoho seredobyscha [Management of aircompany integration potential in the conditions of international competitive environment]. Phormyvannia rynkovyh vidnosyn $v$ Ukraini: zb. nauk. prats, 11(162), $134-138$.

Novak, V. O., Gordienko, I. V., Katerna, O. K., Matveev, V. V., Ilienko, O. V. (2012). Vzaemodiya aeroportu z transportnymy pidpryemstvamy: oranizatsiya ta upravlinnya: [Cooperation of airport with transport enterprises: organization and management]. Kyiv: Kondor. (in Ukrainian)

Bamford, Gomes-Casseres Robinson (2002). Mastering Alliance Strategy: a comprehensive guide to design, management, and organization. Jossey-Bass.

Baum, Rowley, Shipilov (2004). Competing in Groups. Journal of Managerial and Decision Economics [Special Issue].

Bleeke J., Ernst, D. (2001). “Is Your Strategic Alliance Really a Sale?” Harvard Business Review.

Harrigan, K. R. (2002). "Strategic Alliances and Partner Asymmetries”, Cooperative Strategies in International Business. Lexington: Lexington Books.

Kyrylenko, O. M., Shchelkunov, V. I. and oth. (2011). Fundamentals of Transport Economics: Tutorial. Kyiv: Condor.

Novak, V., Symonenko, Y., Lytvynenko, L. (2009). Peculiarities of international strategic alliances activity. International scientific journal. Air transport, 13, 100-107.

Yolles, P. (2005). Strategicheskie alyances v bisnesse [Strategically alliances on business]. Moscow: Dobraya kniga. 